\title{
The Role of Transitions in ESL Instruction
}

\section{Linda Steinman}

Transitions in ESL contexts generally refer to those linking words placed between sentences and between paragraphs. Transitions in writing (and in speaking) are helpful; they facilitate coherence and cohesion when used correctly. Understanding them when reading allows us to join the writer in seeing why and how idea $B$ follows idea $A$. In this commentary I argue that transitions serve the same function in the unfolding of ESL instructional experiences. Instructors have preplanned the choreography, but is it transparent to the students? Should it be? What if we conceive of the ESL lesson as text-an essay in particular?

En anglais langue seconde, quand on parle de transitions, on fait généralement référence aux mots de liaison entre une phrase et une autre, et un paragraphe et un autre. Les transitions sont utiles à l'écrit (et à l'oral); quand elles sont bien employées, elles augmentent la cohérence et la cohésion du message. Quand le lecteur comprend les mots de transition, il voit la suite dans les idées de l'auteur. Dans cet article, j'affirme que les transitions servent la même fonction dans le déroulement des cours d'ALS. Les enseignants prévoient la chorégraphie, mais est-elle transparente pour les élèves ? Devrait-elle l'être? Et si on concevait le cours d'ALS comme un texte - une dissertation, en fait?

Transitions are "explicit linguistic devices to signal relations between sentences and parts of texts" (Connor, 1996, p. 83); "these devices being linguistic resources ... for creating texture" (Halliday \& Hasan, 1976, p. 2) and for providing "textual metadiscourse" (Vande Kopple, 1985, p. 86). Transitions in ESL contexts generally refer to linking words placed between sentences and between paragraphs. Transitions in writing (and in speaking) are helpful: they facilitate coherence and cohesion when used correctly. Understanding them when reading allows us to join the writer in seeing why and how idea $B$ follows idea A. We highlight transitions when addressing writing and reading strategies with our students. In this article, I argue that transitions serve the same function in the unfolding of ESL instructional experiences. Instructors have preplanned the choreography of the lesson, but is it transparent to the students? Should it be? What if we conceive of the ESL lesson as text: an essay in particular?

Transitions as understood in this article refer to micro-transitions such as moving from controlled to free activities as well as to macro-transitions, which include moving from one proficiency level to another. There are four prompts for this commentary on managing transitions in the second-language classroom. One is my experience when participating in a small study 
20 years ago. Another is a 2004 study by Toth (2004). The third prompt is the concept of intersubjectivity-key in Vygotskian sociocultural theory. Finally, I consider the ESL class as a text itself. I describe briefly how each of these phenomena has contributed to my interest in transitions.

About 20 years ago, when working in a community college, I participated in a study in which my task was to observe classes of a freshman course Introduction to Business. I was to sit at the back and note factors in the classroom that would be helpful to ESL students, as well as factors that might interfere with their progress. This was not an ESL class, but as in many college classrooms in Toronto, the number of second-language students was high. I was to review not only class materials, but also the instructor's practices. The instructor was experienced and engaging, and he frequently interspersed personal anecdotes and reflections and his content talk. This usually makes for an enriching learning experience. However, I noted that the ESL students might not have processed the language well enough to be able to distinguish course content-matter that would be on the test-from personal stories, asides, and jokes. That is, some second-language students wrote everything down whereas others seemed to me to be so overwhelmed that they wrote down nothing. In the follow-up session with the instructor, we discussed how he could mark these transitions, either by pausing and headlining "let me stop and tell you a little story"; or using a hand gesture to indicate stop writing; or moving away from his usual lectern position as a cue that he was about to relate an anecdote. These are aspects of instructional design. The study ran out of funds and was not reported, but the memory stayed with me.

The second prompt for this commentary is a study that was memorable because the question being investigated is important to me. In his study entitled When Grammar Instruction Undermines Cohesion in L2 Spanish Classroom Discourse, Toth (2004) examined students' latencies (i.e., their pauses) in a Spanish class as the instructor moved from a focus on form to genuine communication. Classes were videotaped, and remedial sequences were analyzed. Interviews were conducted with participants to confirm what they recalled about the latency. The researcher concluded that students were often confused, not because of language proficiency, but because they were not clear what the instructor expected. Was the instructor communicating genuinely, or was the instructor offering a recast or other type of correction? It was this uncertainty that caused the extended latency: the longer-than-usual pause. The student was processing not only language, but also instructional design. The instructor knew what was going on; the students did not. Advantage-instructor!

For those not familiar with the term recast, here is an example.

Student: A lot of teenagers likes that movie.

Instructor: A lot of teenagers like that movie.

Student: Yes, and I want to see it next week. 
Note that the instructor recasts the student's error (repeats with the correction), but the student hears the recast as a continuation or confirmation of meaning-making and provides an authentic response in the third turn. Lyster and Ranta's (1997) study indicated that although recasts are the most common form of corrective feedback used by classroom ESL instructors, they are not effectively noticed and taken up by students. In his study, Toth (2004) concluded that "for grammar instruction to work effectively, a focus on form must be transparent as the instructional objective" (p. 14). That is, not only should the form itself be clear, but so should the fact that the instructor is going to focus on it. Perhaps there is so much talk of form being incidental that we feel obliged to be surreptitious when focusing on it. The Toth study impressed me as it dealt with micro moments in a classroom. What happens during those exquisite moments when instructor and student actually talk to one another? What can an instructor do to facilitate meaning-making or, conversely, how might she or he impede meaning-making during these moments? Markee (2004) used the term "zone of interactional transition" (ZIT) for this interaction. This is not an appealing acronym, but I like the idea of focusing on that moment in a classroom by naming it.

In sociocultural theory, the concept of intersubjectivity is key and provides the third prompt for this commentary. For development to occur (in the enactment of a zone of proximal development, for example) there must be some common gaze between interactants (such as instructor and learner). One of the narratives in Swain, Kinnear, and Steinman (2010) recounted how a middle-school student in a French immersion program in Ontario was desperate to tell her teacher an important piece of information. Sarah was focused on making meaning, but her teacher, Madame Tremblay, chose this moment to insist that Sarah speak in French and in accurate French. She kept correcting Sarah, and Sarah behaved in a dazed way because the communication had gone awry. She was unable to understand or use language that otherwise would have been quite easy for her because she was confused by how the interaction was evolving. This episode illustrated lack of intersubjectivity between teacher and student, reminiscent of circumstances in the Toth study, and it illustrates a common point of confusion in second-language classrooms. That is, is the communication goal at a particular moment primarily one of making meaning or one of speaking accurately? (Swain et al.).

Finally, to me the ESL classroom is like an essay. It has grammar, rhetoric, a thesis, supports, introduction, conclusion, and so forth. The lesson plan serves the same function as the outline of the essay. If this analogy holds, then for cohesion and coherence to be present, transitions would be key in a lesson just as they are between sentences and between paragraphs. It is important to

[look] at organization of text and clearly [signal] this organization to readers from elementary school through retirement. The factors of 
text organization and signaling of this organization are important when looking at the interaction between the reader and the text in the reading process. (Meyer \& Pollard, 2006, p. 244)

Without signaling, the reader has to generate the relationship between the two sentences; Britton, Glynn, Meyer, and Penland (1982) found that signaling in text reduced the load on working memory during the processing of text. (Meyer, 2003, p. 215)

Clearly the work of Meyer and colleagues was intended for readers (and writers) of text. However, it has been intriguing for me to read across articles related to coherence and to substitute lesson for text, instructor for writer, and student for reader. Much of the advice remains sound despite the transformation. "In addition to the powerful classic readability measures such as word difficulty, the coherence [emphasis added] of a text also must be considered" (Meyer, p. 220). That is, not only content but also organization and signalling add to the complexity of both texts and lessons. This analogy has limits, of course. One hopes that a lesson is more emergent and context-sensitive than an extant text. Although readers interact with and bring their own schemata to a text, the range of flexibility and potential for co-construction is far greater in a classroom. However, I find it thought-provoking to consider how some of the characteristics of good text structure have relevance for good lesson structure.

In this article, I address three areas with respect to transitions in ESL teaching:

1. What are the advantages of making students aware of transitions?

2. How does drawing attention to transitions interact with the goal of "flow"?

3. What are some ways in which instructors might signal transitions to their students?

\section{Advantages of Showing the Seams}

What are the advantages of being clearer about your map-your choreography-your plan for the morning or for the semester? What are the advantages of acknowledging overtly the transitions between, for example, one proficiency level and another, or anecdote and content? What about acknowledging those shifts that are not part of the lesson, but that contribute to students' ability to absorb the lesson such as shifts from one form of language to another or from workplace to classroom?

In considering the above, the sharing of power is relevant. The seamless approach, integrating activities and discourse in a fluid manner, allows only the instructor to imagine both the macro- and the micro-picture of how the hour, or the morning, or the week will unfold. Some students may not need to know the steps in the task, or the timeframe, or the content and linguistic 
outcome(s), but I doubt that any would be disadvantaged by having the instructor share this information with them. Based on research on reading strategies and the advantage offered to readers by activities such as pre-reading, noting organization, signalling, and cohesive markers (Lorch \& Lorch, 1995; Meyer \& Poon, 2001), I argue that a good number of students would find this information helpful and respectful in classroom lessons just as they do in their reading texts. Lesson plans are not goods to be hoarded. I do not believe that instructors intentionally refuse to share plans and the transitions in those plans. However, this knowledge has always been seen as the purview of the instructors and administrators. My commentary calls this mindset (or perhaps habit) into question.

Another reason for clarifying the seams in ESL classroom experiences is that when instructors embed transition practices creatively in their teaching, students become accustomed to these signals and recognize them quickly and effortlessly. This frees up cognitive space for the content of the tasks. Recall the Introduction to Business class I mention as a prompt for this commentary. If the professor had learned to move away from the podium when moving into anecdotal space or had used a hand signal to indicate pens down (or more currently, hands off keyboards), students would have been better able to distinguish the categories of teacher talk. Students should not be confused or stalled by intentions and rationales that are unclear to them. In addition, building overt signals into our teaching requires us to consider carefully why activities, expectations, rooms, and resources are to be changed.

Finally, much is written about scaffolding in education, that is, providing support in the nature and quantity required by students. Signalling throughout activities, across lessons or proficiency levels, breaks what might seem an impenetrable mass into manageable and negotiable chunks. Success can be measured and achieved at various stages. Task boundaries also allow students to prepare mentally for a shift in task and to be better positioned for learning. Like adults, students need both introduction and closure to structure their learning and to make sense of what is being taught. Of course, providing clear yet not laborious transitioning is a fine balancing act.

\section{But What About "Flow"?}

Imagine the wonderful state of creativity, success, and pleasure-oneness with an activity to the point at which there is seamless progression-with the next step being pitched at just the right level of required skill so that students can perform it without getting stalled. This is described as flow by Csikszentmihalyi (1991): "the state in which people are so involved in an activity that nothing else seems to matter; the experience itself is so enjoyable that people will do it even at great cost, for the sheer sake of doing it" (p. 4). Flow is generally considered desirable in creative endeavors (and producing meaning in a foreign language is certainly this type of en- 
deavor). Flow (from the same word root as fluency, according to McCarthy, 2012 ) is to be sought and maintained, certainly when we consider a communicative approach to language learning and teaching. The goal of a flowlike state shows up in many contexts in ESL literature: flow of conversation; flow of group work; flow of a lesson plan. This suggests that the seams should not be apparent. Indeed, Carr (2010), in his book on the effects of the Internet on our brains, asks about the "switching cost" that may result from the continual interruptions that an individual experiences during work or learning. Do the switches (and perhaps overt attention to the switches) distract us, or do they act as important signals, allowing us to treat each interaction in its separate and appropriate context? It is an intriguing question. When is flow beneficial, and when does flow become an unmanageable torrent of unmarked switches?

For a moment, think of the language lesson as a communication act, as an essay, as a dance, or as a trip. What seems more important: the flow or the markers telling us where we are in that essay, in that dance, on that trip, and why? And when thinking about the essay, the dance, and the trip, did you put yourself in the role of the doer or the done to- that is, the writer or the reader? The trip planner or the tourist? The dancer or the audience? Does this change the role of transitions and your response to the value of seams? In each of these activities, seams might be more or less important. The trend in second- and foreign-language teaching over time has been to remove seams. In his discussion of "signature pedagogies," Ciccone (2009) suggested that language-learning classes in the past were like "a forced march through linguistic forms" compared with graduate seminars, which were more like "a creative dance" (p. xi). There are likely to be times when we want transitions in the language-learning class to be seamless, when we want not to alert students to transitions. Teaching involves making choices between flowing and overt transitioning. Sometimes we march; sometimes we dance.

\section{How Do We Signal Transition Points?}

Once we have considered the need for transitions (a greater or lesser need, but a considered need) how might we signal to our students that we are pivoting in some way? This brings to mind the "moves" in Swales' (1990) theory of writing. First, instructors should signal the transitions to themselves in our written lesson plans, and then use them in the enactment of the plan. If it turns out that the transitions are not sufficient (or conversely, too plentiful), then the revision of the plan would include this adjustment. In this article, I focus on the local transitions in the lesson of the day. Today, however, with the capacity to show slides using presentation software in so many classroom, detailed agendas can remain evident throughout the course. Course outlines and schedules might be quite detailed, demonstrating progress through the ranks; the trajectory and the boundaries across longer stretches 
of curricula and settings would be helpful to many students. It might be useful for instructors to ask themselves whether their students clearly understand what is to be covered for the day, the week, the proficiency level, across levels. Can they look backward and look ahead, or is that privileged information reserved for the instructor and program coordinators? A program document or Web site should allow students to see (and review with or without the instructor) how the skills acquired will be revisited and built on from level to level.

What needs to be in place for transitions to occur successfully? It seems reasonable that providing the time element is orienting for students. When I presented a version of this article at a conference attended by ESL instructors (Steinman, 2012), comments from participants affirmed that advising students how much time they have for an activity or a portion of an activity is both respectful and helpful. As well, repetition and restatement of the shift are in order. As is true of many types of interaction with students (not only transitional moments), comprehension checks are beneficial, for example, "Marco, please remind us what are we about to do" "Sara, please tell us in your own words, what we are doing next and why."

Accommodation is relevant to the topic of transitions. Instructors should ensure that students have the skills for the transition. If they have doubts, perhaps the transition needs to be broken down into component steps. Further, it may be necessary to provide

proximity by positioning yourself nearby individual students who may require support when making transitions from one activity to the next ... Some students may require additional time to transition from one activity to the next, and may benefit from beginning the transition earlier so they can start the next activity at the same time as the other students. (Supporting behaviour and social participation of all students, n.d.)

These are the considerations in which instructors engage during the lessonplanning stage. They should be ready to provide or suggest options or adaptations for those who are not yet able to make the full transition. I was reminded of the concept of universal support when visiting a Canadian Web site that addresses transitions between and within activities in support of all student learning (Supporting behaviour and social participation of all students, n.d.). The philosophy behind universal support is that what is helpful to some students who require special accommodation is often helpful to all students. "Using prearranged signals, such as a chime, a piece of recorded music or a sign on the board can serve as gentle non-verbal reminders that a transition is to begin three to five minutes before the actual transition time." I was drawn to this suggestion, because when teaching lower proficiencylevel classes in particular, I try to develop as many gestures as possible to re- 
duce my talking time. And as a language student, a position in which I put myself regularly, I am always grateful when instructors use relaxing, easyto-process manoeuvres.

In this article, I consider the role of transitions. I suggest that pivots, that turning points at both the micro-level (within a lesson) and macro-levels (across units or programs), should be considered. Making transparent the turning points shares power with students, provides scaffolding for many, and requires instructors to think deeply about the choreography of the lesson. Overt transitioning ("showing the seams" as I refer to it) allows students to reserve cognitive processing for the lesson content itself. Outcomes are likely to be more positive when students have seen the map in advance. Alongside, and perhaps contrary to, the conversation about overt transitioning is the appealing goal of flow-of being in the moment with a creative act to the point at which one is not aware of any seams-each subsequent step follows naturally and easily from the previous one. In this state, progression (development, learning) has energy of its own. I suggest that thought be given to points in the lesson or in the curriculum where seams need to be clear and at points where instructors feel confident that students will experience flow. I return to the analogy of the lesson as an essay and invite instructors to consider for themselves whether the role of transitions in an essay is similar to the role of transitions in their language classroom.

\section{The Author}

Linda Steinman is an associate professor at York University in Toronto, where she currently teaches credit ESL and graduate courses in applied linguistics. She has been involved in and intrigued by the field of ESL since the 1970s.

\section{References}

Carr, N. (2010). The shallows: What the internet is doing to our brains. New York: W.W. Norton.

Ciccone, A.A. (2009). Foreword. In R.A.R. Gurung, N.L. Chick, \& A. Haynie (Eds.), Exploring signature pedagogies: Approaches to teaching disciplinary habits of mind (pp. xi-xvi). Sterling, VA: Stylus.

Connor, U. (1996). Contrastive rhetoric: Cross-cultural aspects of second-language writing. Cambridge, UK: Cambridge University Press.

Csikszentmihalyi, M. (1991). Flow: The psychology of optimal experience. New York: Harper Perennial.

Halliday, M.A.K., \& Hasan, R. (1976). Cohesion in English. New York: Longman.

Lorch, R.F., Jr., \& Lorch, E.P. (1995). Effects of organizational signals on text-processing strategies. Journal of Educational Psychology, 87, 537-544.

Lyster, R., \& Ranta, L. (1997). Corrective feedback and learner uptake: Negotiation of form in communicative classrooms. Studies in Second Language Acquisition, 19(1), 37-66.

Markee, N. (2004). Zones of interactional transition in ESL classes. Modern Language Journal, $88,583-596$.

McCarthy, M. (2012, October). Grammar at the upper levels: Exploiting corpus evidence. Paper presented at the TESL Canada Conference, Kamloops, BC.

Meyer, B.J.F. (2003). Text coherence and readability. Topics in Language Disorders, 23, 204-224. 
Meyer, B.J.F., \& Pollard, C.K. (2006). Applied learning and aging: A closer look at reading. In J.E. Birren \& K. Warner Schaie (Eds.), Handbook of the psychology of aging (6th ed., pp. 233261). Burlington, MA: Elsevier Academic Press.

Meyer, B.J.F., \& Poon, L.W. (2001). Effects of structure strategy training and signaling on recall of text. Journal of Educational Psychology, 93, 141-159.

Steinman, L. (2012, November). Transitions in the second language classroom. Paper presented at the annual TESL Ontario Conference,Toronto.

Supporting behaviour and social participation of all students. (n.d.). Transitioning between activities. Available:

http:/ / www.learnalberta.ca/content/insp/html/transitioning_between.html

Swain, M., Kinnear, P., \& Steinman, L. (2010). Sociocultural theory in second language education: An introduction through narratives. Bristol, UK: Multilingual Matters.

Swales, J.M. (1990). Genre analysis: English in academic and research settings. Cambridge, UK: Cambridge University Press.

Toth, P.D. (2004). When grammar instruction undermines cohesion in L2 Spanish classroom discourse. Modern Language Journal, 88, 14-30.

Vande Kopple, W.J. (1985). Some exploratory discourse on metadiscourse. College Composition and Communication, 36(1), 82-93. 